\title{
Grammaticalization in Seychelles Creole:
}

\section{the coding of reciprocity by kanmarad}

\section{Sibylle Kriegel}

\author{
In memory of Marcel Rosalie
}

\author{
Aix Marseille Univ, CNRS, LPL \\ sibylle.kriegel@univ-amu.fr
}

Received: 18-06-2021

Accepted: 31-08-2021

Published: 09-09-2021

How to cite: Kriegel, Sibylle. 2021. Grammaticalization in Seychelles Creole: the coding of reciprocity by kanmarad. Isogloss. Open Journal of Romance Linguistics 7,11: 1-27.

DOI : https://doi.org/10.5565/rev/isogloss.149

\begin{abstract}
Seychelles Creole (SC) is one of the few creoles with a grammaticalized reciprocity marker. The grammaticalized use of kanmarad (< Fr. camarade 'comrade, companion') is mentioned in the grammars of SC (Bollee 1977; Corne 1977; Choppy 2009) but its evolution and distribution in modern SC have never been analyzed. This contribution first presents present-day data from spoken and written corpora of SC and compares them to data published in the Atlas of Pidgin and Creole Language Structures, APiCS (Michaelis \& al. 2013). Appealing to several grammaticalization mechanisms discussed in the literature, it then traces back the grammaticalization process of kanmarad, a process that is not very advanced in the closely related Mauritian Creole (MC). In accordance with Michaelis \& Haspelmath (2020), the evolution of kanmarad in SC can be interpreted as an instance of accelerated functionalization which the authors consider to be typical of creole languages. Ultimately, the study's findings are discussed in light of two complementary hypotheses that try to explain the acceleration of functionalization: the Extra-Transparency Hypothesis (Haspelmath \& Michaelis 2017) and the Distinction during Codification Hypothesis which I suggest for SC. Both are
\end{abstract}


considered to be possible factors favoring an ordinary language-internal grammaticalization process.

Keywords: Accelerated functionalization; Distinction during Codification Hypothesis; Extra-Transparency Hypothesis; grammaticalization; Mauritian Creole; reciprocity; Seychelles Creole

\section{Table of Contents}

$\begin{array}{cc}\text { 1. Introduction } & \text { 4. Possible motivations for the } \\ \text { 2. Kanmarad in SC and the data from } & \begin{array}{c}\text { grammaticalization of kanmarad } \\ \text { ApiCS }\end{array} \\ \begin{array}{c}\text { 5. Conclusion } \\ \text { 3. The grammaticalization of } \\ \text { kanmarad }\end{array} & \text { References }\end{array}$

\section{Introduction}

SC, the first national language of the Republic of Seychelles, is one of the few creole languages possessing an innovative and grammaticalized marker of reciprocity - a lexical item that has been freshly grammaticalized. Although the token frequency of the reciprocal construction with kanmarad ( $<$ Fr. camarade 'comrade, companion') $)^{1}$ is not very high, I observed during recent fieldwork that it is used in all language registers. The following is an example from spontaneous oral speech of a Seychellois herbalist who explained in an informal conversation the ecology of medicinal plants he grew in his garden.

(1) $\mathrm{SC}^{2}$

$\begin{array}{lllllll}\text { Sa bann } & \text { plant } & \text { i } & \text { pous } & \text { an } & \text { fanmir zot } & \text { pa } \\ \text { ARTPL } & \text { plante } & \text { 3SG } & \text { pousser } & \text { en } & \text { famille 3PL } & \text { NEG } \\ \text { ARTPL } & \text { plant } & \text { 3SG } & \text { grow } & \text { in } & \text { family 3PL } & \text { NEG }\end{array}$

$\begin{array}{ll}\text { detas } & \text { kanmarad } \\ \text { détacher } & \text { RECP } \\ \text { pull.away } & \text { RECP }\end{array}$

'Plants grow in families. They don't pull away from one another.' (Vidot-Rosalie corpus 2017)

Was this just a metaphorical expression, some kind of humanization of the plants he was talking about? I do not think so and this study aims to explain why.

$\mathrm{SC}$ is the native language of about $95 \%$ of the Seychelles' population and is spoken by some 85,000 speakers. It is considered to be a continuation of stable varieties of Mauritian

1 Given the multiple writing conventions and the comparative perspective of this study I use the term 'companion'-based reciprocal construction (see APiCS).

$2 \quad$ My corpus examples are given with an interlinear version that follows the Leipzig glossing rules. The glosses are first given in French, the lexifier language of SC, followed by an English version. 
Creole (MC) that were imported at the end of the $18^{\text {th }}$ century ${ }^{3}$. Modern MC and modern SC are mutually intelligible. In both countries we are witnessing an increased use of creole in formal contexts as a consequence of independence. This use is however much more common in Seychelles than in Mauritius where the creole language has no official status. This paper will focus on the use of kanmarad, which is slightly different between the two languages and has to be considered an example of the few differences between the two varieties on the morphosyntactic level.

Contact-induced language change has been a much-discussed topic in recent years and creole formation has been an important area of interest in this field of study. A great deal of attention has been paid to contact-induced grammaticalization in creole formation (e. g. Bruyn 1996, 2009; Hopper \& Traugott 2003; Kriegel ed. 2003; Plag 2002; McWhorter 2018) and in other language contact situations (e. g. Heine \& Kuteva 2003, 2005). Michaelis \& Haspelmath (2020) state: "A very important phenomenon that interacts with grammaticalization in creole languages is 'semantic imitation' of substrate languages". Different cases of what Michaelis \& Haspelmath (2020) summarize as "semantic imitation" have been discussed in the literature under different rubrics, e. g. ordinary contact-induced grammaticalization (Heine \& Kuteva 2003, 2005), apparent grammaticalization (Bruyn 1996, 2009), and polysemy copying (Heine \& Kuteva 2003). As Bruyn (2009) points out, distinguishing among these different mechanisms, although necessary, proves to be difficult in practice. This paper discusses the evolution of kanmarad into a grammaticalized marker of reciprocity in modern SC in the light of these approaches to grammaticalization. I argue that the evolution of kanmarad is not due to substrate influence (section 2.3) but can be explained by an ordinary language-internal grammaticalization process (section 3). This result is consistent with McWhorter's (2018) claims that "there is no 'creole' kind of grammaticalization" and that "grammaticalization has indeed occurred to an unusually vast degree in the few centuries that most creoles are known to have existed" (McWhorter 2018). Further, my explanation will appeal to the idea of accelerated functionalization put forward by Michaelis \& Haspelmath (2020) (section 4.1). Of course, my argument in no way negates the fact that contact-induced change has occurred in other areas of SC morphosyntax.

In Sections 2.1 and 2.2, I present and compare data from spoken and written modern SC with data from APiCS (Atlas of Pidgin and Creole Language Structures) and with data from other languages. Section 2.3 addresses the question of possible contact-induced change. Section 3 deals with the grammaticalization of kanmarad. Using data from both earlier and contemporary SC and MC, I discuss several grammaticalization mechanisms that played a role in the grammaticalization of kanmarad. Lastly (section 4), after a brief discussion of the notion of accelerated functionalization suggested by Michaelis \& Haspelmath (2020), I consider possible reasons for the emergence of the 'companion'-based reciprocal construction. I discuss the Extra-Transparency Hypothesis and the Distinction during Codification Hypothesis as possible factors favoring an ordinary language-internal grammaticalization process.

\section{Kanmarad in SC and the data from APiCS}

I am interested in the morphosyntactic marking of reciprocal constructions without focusing on their highly complex semantics (see e. g. Nedjalkov 2007). I am perfectly aware of the fact that, as in many languages, reciprocity can stay unmarked, above all with symmetrical verbs (Haspelmath 2013) as illustrated in (2).

3 Chaudenson (e. g. 2013) also considers the input from Bourbonnais, less important than the one from MC. 
(2) SC

Pyer ek Lise pe anbrase.

Pierre avec Lise PROG embrasser

Peter with Lise PROG kiss

'Pyer and Lise are kissing/hugging.' (data elicitation)

However, I concentrate on morphosyntacticly marked examples with a special focus on the 'companion'-based reciprocal construction.

\subsection{The data in modern $S C$}

The first linguists to observe the evolution of the lexeme kanmarad as a reciprocal pronoun in SC were Bollée and Corne, in their grammars, both published in 1977. Bollée gives the following example:

5.3.4.1. Le pronom de la réciprocité est kamarad (v. § 4.6.2):

Zot ti apel kamarad par zot nõ gate.

'Ils s'appelèrent entre eux par des diminutifs.' (Bollée 1977: 66)

(5.3.4.1. The reciprocity pronoun is kamarad (v. $\S 4.6 .2)$ :

Zot ti apel kamarad par zot nõ gate.

'They called one another by pet nicknames.' (my translation))

Choppy (2009: 90), the only pedagogical grammar of SC, lists different ways of expressing reciprocity and mentions kanmarad in the first place:

An K.S. nou eksprim resiprosite an servan:

(i) 'Kanmarad'

Leg: Sa de dimoun i kontan kanmarad.

(ii) 'sakenn'

Leg: Zot pa ti kapab apel sakenn zot prop non.

(iii) 'ansanm'

Leg: Zot ti koz ansanm.

(iv) 'enn a lot'

Leg: Zot ti a detri enn a lot parey zannimo. (Choppy 2009: 90)

(In SC we express reciprocity by using:

(i) 'kanmarad' ('comrade, companion')

Example: These two people love one another.

(ii) 'sakenn'

Example: They were not able to call each other by their own name.

(iii) 'ansanm'

Example: They talked to each other.

'enn a lot' ('one another')

Example: They would destroy one another like animals. (my translation))

Let me concentrate on the first technique with kanmarad and add examples from spontaneous oral speech as well as data drawn from written registers.

(3) SC

Plant ek plant osi i ed kanmarad, enn a lot. 
Plante avec plante aussi 3SG aider RECP un à autre

Plant with plant also 3SG help RECP one to other

'Amongst themselves, plants also help one another.' (Vidot-Rosalie corpus 2017)

(4) SC

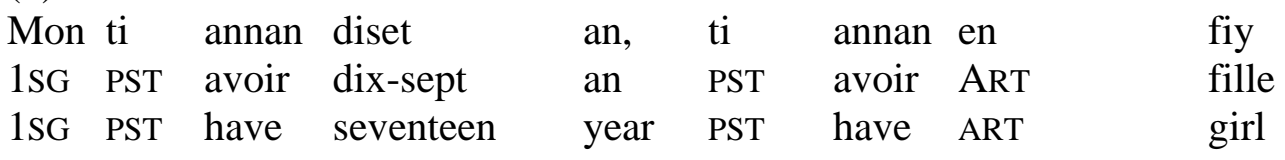

ti annan sez an, nou 'n kontan kanmarad.

PST avoir seize an 1PL PRF contentRECP

PST have sixteen year 1PL PRF happy RECP

'I was seventeen years old, there was a girl who was sixteen, we were in love with each other/we were lovers.' (Vidot-Rosalie corpus 2017)

(5) SC

$\begin{array}{llll}\text { Zot konn } & \text { koz angle } & \text { sa } & \text { bann, } \\ \text { 3PL connaître } & \text { causer anglais } & \text { DEM } & \text { PL } \\ \text { 3PL know } & \text { chat English } & \text { DEM } & \text { PL }\end{array}$

zot pe zour kanmarad an angle.

3PL PROG jurer RECP en anglais

3PL PROG insult RECP in English

'They know how to speak English, they are insulting one another in English.' (Unpublished interview of National Heritage, recorded in 1983 with Félix Jolicoeur)

(6) SC

Zot ti 'n konn kanmarad depi zot adolesans 3PL PST PRF connaître RECP depuis POSS.3PL adolescence 3PL PST PRF know RECP from POSS.3PL adolescence 'They have known each other since they were teenagers.' (Vel, Latet par lao delo, forthcoming)

(7) SC

$\begin{array}{lll}\mathrm{i} \text { ti } & \text { demann } & \text { mwan, } \\ \text { 3SG PST } & \text { demander } & \text { 1SG.OBJ } \\ \text { 3SG PST } & \text { ask } & \text { 1SG.OBJ }\end{array}$

son de lanmen krwaze dan kanmarad.

POSS deux main croiser dans RECP

POSS two hand cross in RECP

'She asked me, with her hands folded.' (T. Dick, Pti Piman for, 2016)

(8) SC

$\begin{array}{llllll}\text { Sa farmasi } & \text { i } & \text { travay } & \text { an } & \text { kolaborasyon avek } \\ \text { ARTpharmacie } & \text { 3SG } & \text { travailler } & \text { en } & \text { collaboration avec } \\ \text { ARTpharmacy } & \text { 3SG } & \text { work } & \text { in } & \text { collaboration with }\end{array}$

Lopital Logan, dan en partenarya

Hôpital Logan dans ART partenariat 


\begin{tabular}{llll}
\multicolumn{2}{l}{ Hospital Logan } & in & ART partnership \\
kot & zot & konplimant & kanmarad. \\
où & 3PL & compléter & RECP \\
where & 3PL & complete & RECP
\end{tabular}

'The pharmacy works in collaboration with the Logan-Hospital, in a partnership in which they complement one another.' (Seychelles Nation 8-11-2016)

Among the alternative techniques mentioned by Choppy (2009) (see above), only enn a lot is restricted to the expression of reciprocity as it is the case for kanmarad. I will briefly discuss this expression: enn a lot derives from the French pattern un à l'autre ('one another') (Guentchéva \& Rivière 2007) and also exists in several other French-based creoles (see table 1). Besides the example given in Choppy (2009) it can be found in corpus example (3), in which the speaker uses kanmarad and, additionaly, enn a lot to reinforce his statement (also see Bollée 1977: 50-51). As to example (3), my Seychellois colleagues gave me the following information: "Kanmarad can be left out here with no change in meaning. In fact, enn a lot is a synonym of kanmarad in this context." (Penda Choppy, p.c.) The use of enn a lot is not mentioned by Michaelis \& Rosalie (2013) (APiCS). The only example in our spoken corpora is example (3) where enn a lot is used in addition to kanmarad. A variant with the agglutinated French definite article $l^{\prime}$ is attested in an example drawn from a written register ${ }^{4}$ :

(9) SC

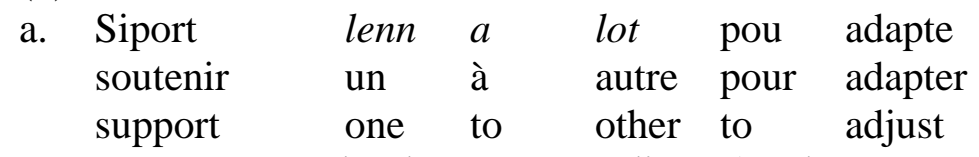

'to support each other so as to adjust' (Verbatim Report, National Assembly of Seychelles, https://www.nationalassembly.sc)

Data elicitation revealed that (l)enn a lot can be used as an alternative to kanmarad in some contexts. Its use can be considered to be marginal. Its French model, the compound reciprocal pronoun l'un l'autre is marked for gender and number and takes prepositions which are inserted between the two components (Guentchéva \& Rivière 2007: 564). The prepositions change following to the valency pattern of the verb. In addition to this complex morphosyntactic behavior, the use of l'un l'autre is semantically restricted (for details Guentchéva \& Rivière 2007: 564). In addition to the frozen form (l)enn a lot going back to a verb used with the preposition $\grave{a}$ attested in our oral corpus of SC (example 3) and in example (9a) with agglutination of the French article, attestations with verbs introducing their complement by other prepositions are sparse. Example (9b) is drawn from a written register:

(9) SC

b. Annou kontinyen siport lenn e lot A nous continuer soutenir l'un et l'autre Let us continue support one and other 'Let us continue to support each other' (Mesaz Prezidan Danny Faure, 24 December 2019, Facebook)

Data elicitation revealed that forms like $(9 \mathrm{c})$

\footnotetext{
$4 \quad$ I would like to thank an anonymous reviewer who drew my attention to examples (9a) and (9b).
} 
(9) SC

c. ?Pyer ek Lise pe lager enn ek lot.

Pierre avec Lise PROG guerre un avec autre

Pierre with Lise PROG fight one with other

'Pyer and Lise are fighting with each other.'

are felt to be grammatically correct but "not really used by the Seychellois community" (Penda Choppy, p.c.).

\subsection{Comparison with other creole and non-creole languages}

In WALS (World Atlas of Language Structures, Maslova \& Nedjalkov 2013) as well as in APiCS, the chapter about reciprocal constructions (Haspelmath 2013) deals almost exclusively with the question of whether reciprocal and reflexive construction have the same marking - this is the case in a lot of languages (German: 'Alfred und Bernhard schlagen sich', French: 'Alfred et Bernard se frappent.'). This question is not central to my study because the French-based creoles have lost the clitic personal pronoun 'se' (and its equivalents for other persons) and have developed partially innovative techniques to mark reflexivity ${ }^{5}$, on the one hand, and reciprocity, on the other. This is the reason why this study considers only the values linked to reciprocal constructions not identical to the reflexive, so-called special reciprocal constructions (APiCS), with a special focus on the French creoles.

Figure 1. Reciprocal constructions in creole, pidgin, and mixed languages, feature 89, APiCS
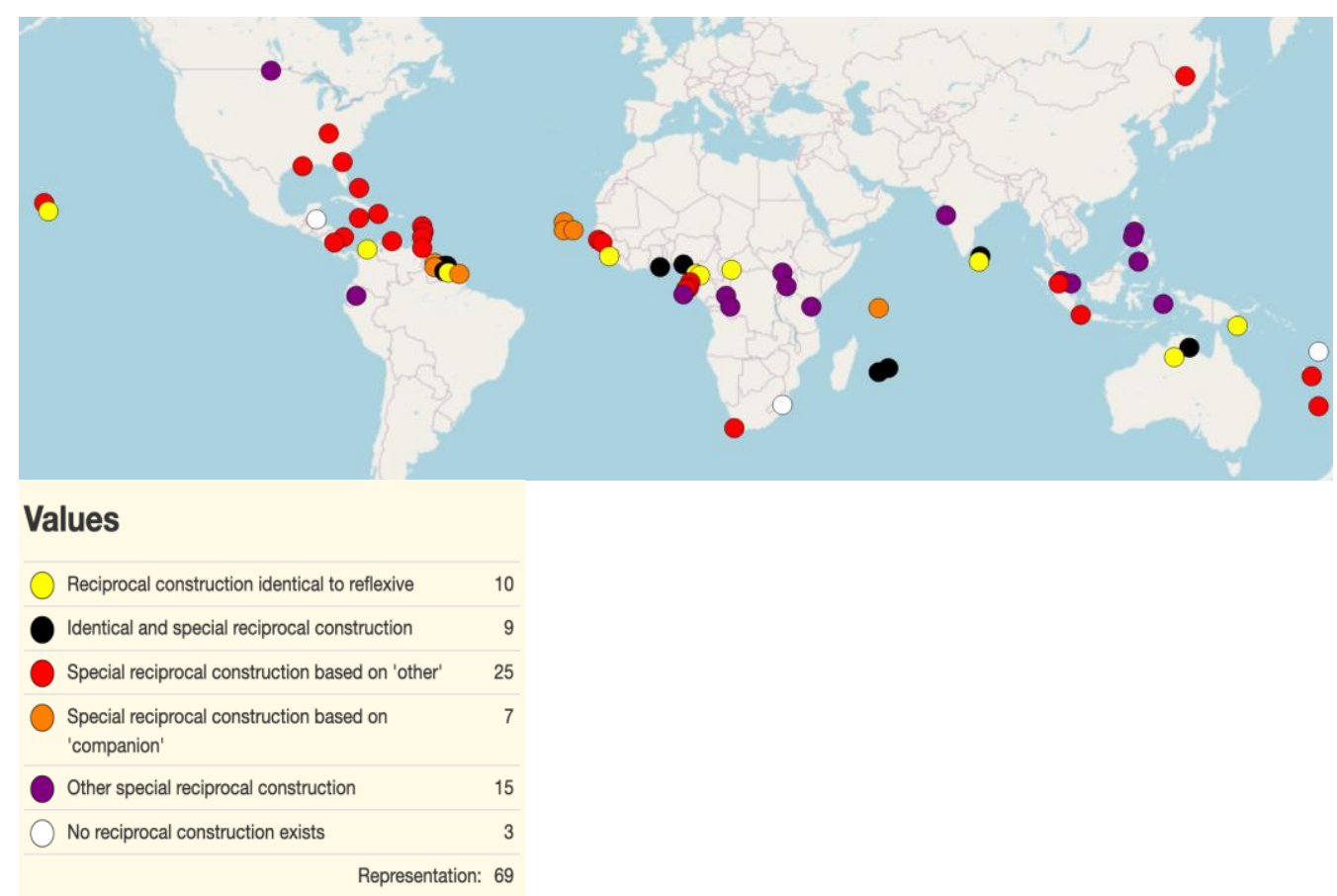

Source: https://apics-online.info/parameters/89\#2/10.1/4.7

Most French creoles belong to the group of creoles with a special reciprocal construction based on 'other' which maintains the French pattern l'un l'autre (used in

$5 \quad$ The French creoles use body part reflexives and, alternatively, the object form of the personal pronoun, often followed by an intensifier (e. g. Kriegel \& Ludwig \& Pfänder 2019). 
addition to the clitic personal pronoun). As has been shown in section 2.1, in SC the use of (l)enn a lot based on 'other' is also a marginal possibility.

Table 1. Reciprocal constructions based on 'other' in French creoles, APiCS

\begin{tabular}{|l|l|}
\hline Guadeloupean Creole & lòt \\
\hline Haitian Creole & lòt \\
\hline Louisiana reole & enn-a-lot \\
\hline Martinican Creole & lot \\
\hline Mauritian Creole & len a lot (Syea 2013: 207) \\
\hline Reunion Creole & enn-é-lot \\
\hline Seychelles Creole & (l)enn a lot (marginal, see section 2.1) \\
\hline Tajo & atr \\
\hline
\end{tabular}

I am mainly interested in the orange dots which refer to a special reciprocal construction based on 'companion'. Three French creoles are represented: Guianese French Creole, MC and SC.

Table 2. Reciprocal constructions based on 'companion' in French creoles, APiCS

\begin{tabular}{|l|lc|}
\hline Guianese French Creole & $\begin{array}{l}\text { Determiner + kompannyen } \\
\text { examples (10) and (11) }\end{array}$ \\
\hline MC & $\begin{array}{l}\text { Determiner + kamarad (not } \\
\text { grammaticalized, see section 3.3) }\end{array}$ \\
\hline SC & Kanmarad \\
\hline
\end{tabular}

As MC will be studied in more detail in Section 3.3, I will briefly consider the situation in Guianese French Creole: The first novel in a French Creole is Atipa, written in 1885 in Guianese French Creole by Alfred Parépou, a pseudonym for an unknown writer (but see Wiesinger 2017: 34). It contains two examples with the lexeme compagnin used in a context where a reciprocal reading is the most convincing interpretation (compare the two French translations of (10): 'Ils se dirent bonsoir', translation by M. Fauquenoy in Parépou 1885:205 and 'Ils se souhaitèrent le bonsoir', translation by M. Lohier in 1980, MarieChristine Hazaël-Massieux, p.c.).

(10) Early Guianese French Creole

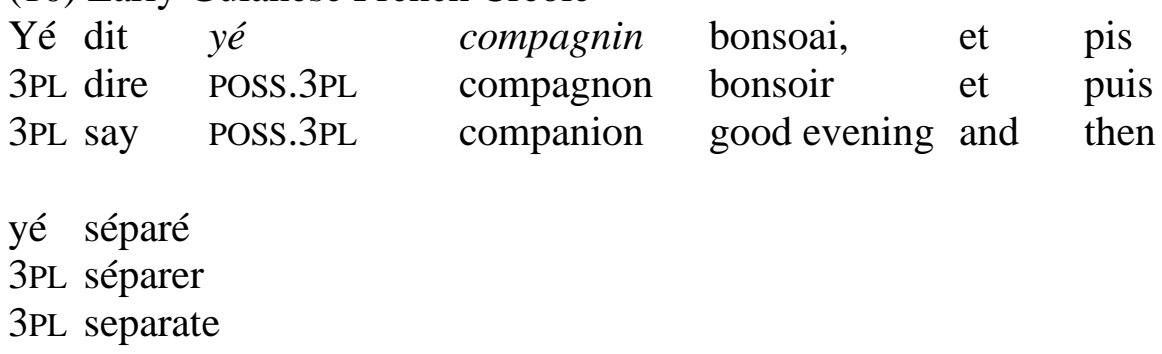

'They say goodbye to one another and go their separate ways.' (Parépou 1885: 204)

6 I would like to thank the anonymous reviewers who mentions the existence of an earlier form without the agglutinated French definite article l', quoted by Baissac (1880: 22): "L'un l'autre. Une construction récente place la préposition à entre les deux pronoms pour marquer la réciprocité. Ex. : Mariez-les vite, ils s'aiment, Marié zautes vitement, zautes content éne à laute. 
A comparable corpus example from modern Guianese French Creole is cited by Jennings \& Pfänder (2018: 150). It should be noted that unlike in modern SC the possessive determiner is used in both examples (10) and (11).

(11)

Wonm-yań tchoué yé kompannyen

Men-DEF kill 3PL RECP

'They killed each other.' (Jennings \& Pfänder 2018: 150)

According to APiCS, the other creole languages to possess a special reciprocal construction based on 'companion' are the three varieties of Portuguese-based Cape Verdean Creole as well as Berbice Dutch and Creolese, the English-lexifier Guyanese Creole spoken in vicinity of Berbice Dutch.

Beyond creole languages and in a wider perspective of language typology, reciprocal constructions based on 'companion' exist in several unrelated languages throughout the world. Evans (2008: 52) reports cases from Zapotec spoken in Mexico. Heine \& Kuteva (2002: 92) quote examples from Russian, from several West African languages of the NigerCongo family (Gabu (Adamawa-Ubangi), Gola (West Atlantic), Fulfulde (West Atlantic), Koromfe (Voltaic)) as well as from SC. They state: "More research is required on the exact nature and the genetic and areal distribution of this process. This is an instance of a process whereby concrete nouns are grammaticalized to pronouns expressing relations among clause participants." (Heine \& Kuteva 2002: 93) ${ }^{7}$

\subsection{The possibility of contact-induced change as an explanation}

I will now examine the possibility that the 'companion'-based reciprocal construction of SC could be the result of contact-induced change. As stated in section 1, SC can be considered to be a form of MC that was imported at the end of the $18^{\text {th }}$ century. Though there was a short period (1727-1735) at the beginning of the colonization of Mauritius when West African slaves were imported, the main substrate languages present in the Mascarenes (today Reunion and Mauritius) after 1760 were Malagasy and several Eastern Bantu languages. After the abolition of slavery in 1835 another wave of Eastern Bantu speakers arrived in the Seychelles $^{8}$. The 'companion'-strategy for forming reciprocals is not present in the main substrate languages of SC. Malagasy uses the infix -if- in combination with the prefix $m-{ }^{9}$ As to Eastern Bantu ${ }^{10}$, the dominant pattern marked by -ana is clearly not related to 'companion'

7 For a discussion of the strategy concerning nouns meaning 'comrade', 'mate', 'companion', 'friend', etc., as well as examples from a wider range of languages see Heine \& Miyashita (2008: 178181).

8 As a lot of speakers of Tamil arrived in the Seychelles after the abolition of slavery it is also interesting to check data from Tamil: According to Annamalai (2000), the reciprocal pronoun in Tamil is not related to a lexical item of the type kanmarad. "The reciprocal form is the reduplication of the nominal form oru 'one' with gender and number appropriate to the subject." (Annamalai 2000: 175)

$9 \quad$ 'c) Verbes réciproques: Pour exprimer l'idée de réciprocité il faut rajouter l'infixe -if ou ses variantes -ifamp et -ifank au préfixe m-: Exemples: - mifanojo/ se rencontrer - mifampijery/se regarder - mifankatia/s'aimer.' (Jaozandry 2014)

(c) Reciprocal verbs: To express the idea of reciprocity, you must add the infix -if or its variants ifamp and -ifank to the prefix m-: Examples: -mifanojo/to meet - mifampijery/to look at one another - mifankatia/to love one another (my translation)).

10 Woodward (1926: 306) states in his grammar of Makwa, one of the most probable substrate languages for SC: "Reciprocal form: This is made by changing the final -a into -ana: wiwa, to hear; wiwina, to hear one another; wata, to beat; watana, to fight." 
but goes back to a NP conjunction marker. ${ }^{11}$ In addition, Maslova (2007: 350) mentions other strategies to express reciprocity using body-part reflexives in several Bantu languages, but does not mention the existence of 'companion'-based reciprocals.

The situation is different in the case of the other creole languages possessing a 'companion'-based reciprocal construction (see section 2.2), it is highly probable that its existence can be explained by substrate influence from West African Niger-Congo languages. So, for Guianese French Creole Jennings \& Pfänder (2018: 150) explicitly mention an example from Ewe and observe: "This syntactic strategy [the 'companion'-strategy, S.K.] may be a transfer from the very similar Ewe strategy." Even if theoretically West African influence in SC via MC cannot be excluded, most of the enslaved people spoke languages that are not good candidates as models for 'companion'-based reciprocals. It should also be pointed out that the grammaticalized use of kanmarad as a reciprocal is limited to SC and that in MC the grammaticalization process is less advanced (see section 3.3). In conclusion, it is improbable that there is a West African model for the kanmarad reciprocal in SC.

\section{The grammaticalization of kanmarad}

In this section, I discuss several processes or mechanisms of grammaticalization (see e. g. Hopper 1991, Bybee 2015) relevant to the evolution of kanmarad into a grammaticalized marker of reciprocity. Among these are divergence (Hopper 1991: 24-25; Hopper \& Traugott 2003: 118-122), semantic generalization or bleaching ${ }^{12}$ (e. g. Bybee 2015: 130-132), and decategorialization (Hopper 1991: 30-31; Hopper \& Traugott 2003: 106-111; Bybee 2015: 129-132). I also appeal to native speaker judgments to test the mechanism of specialization (Hopper 1991: 25-28; Bybee 2015: 125-127).

\subsection{Non-grammaticalized uses in modern SC-the process of divergence}

In section 2.1, I presented corpus data containing a 'companion'-based reciprocal construction that is clearly grammaticalized. I now want to trace back this grammaticalization process. But firstly, it is important to state that kanmarad continues to exist as a full lexical noun, completely independent from a reciprocal interpretation in SC:

(12) SC

$\begin{array}{llllll}\text { Son } & \text { kanmarad } & \text { i } & \text { la } & \text { anler } & \text { i } \\ \text { POSS.3SG } & \text { camarade } & \text { 3SG } & \text { là } & \text { en l'air } & \text { 3SG } \\ \text { POSS.3SG } & \text { comrade } & \text { 3SG } & \text { here } & \text { in the air } & \text { 3SG }\end{array}$

fer fernwar.

faire nuit

make night

'His companion [the fool, species of bird] is here in the air, it is nighttime'. (Bollée \& Rosalie 1994: 186)

The status of kanmarad in example (12) is clearly lexical: It is used in subject position and could easily be exchanged with other lexemes like zanmi, dalon 'friend' (data elicitation). Moreover, the presence of the possessive determiner son shows that we are dealing with a

11 Maslova (2007: 343) quotes Schladt (1996), who argues in favor of the existence of a grammaticalization path.

12 For a critical discussion of the term "bleaching" see Hopper \& Traugott (2003: 94-98). I systematically use "semantic generalization or bleaching". 
noun. The use of kanmarad as a full lexeme is mentioned in the relevant dictionaries (DECOI, Bollée 2000: 203) which contradicts König \& Haas' statement: "La grammaticalisation de kamarad en marqueur de réciprocité est confirmée par le fait que kamarad ne s'emploie plus comme lexème indépendant". (König \& Haas 2007: 144) (The grammaticalization of kamarad as a marker of reciprocity is confirmed by the fact that kamarad is no longer employed as an independent lexeme. (my translation))

The existence of kanmarad as an independent lexeme in no way contradicts an interpretation as an instance of grammaticalization. It simply illustrates its synchronic dimension. Raible (1992: 263) speaks of the "Gleichzeitigkeit des Ungleichzeitigen", the simultaneity of the non-simultaneous, Hagège calls it "le principe de la Preuve par Anachronie", the principle of the proof by anachrony (Hagège 2001: 1617), Roberts \& Roussou label it "lexical split" whereas Hopper (1991: 22) and Hopper \& Traugott (2003: 118-122) speak of divergence.

Grammaticalized uses of camarade, even incipient grammaticalization, do not exist in the lexifier language French. This observation is important because work on grammaticalization in creole languages should not neglect the possibility that grammaticalization may have started in the varieties of the lexifier language present in the creolization process. This is for instance the case of the reflexive marker son lekor (see Kriegel \& Ludwig \& Pfänder 2019). In the case of camarade, the first attestation found in the FEW is in Middle French from 1560 where the lexeme is used in the sense of 'chambree de soldats', a soldier's barrack

(FEW), https://apps.atilf.fr/lecteurFEW/index.php/page/lire/e/47251. The FEW does not mention uses from Regional Frenches that could be interpreted as incipient grammaticalization.

\subsection{From old ${ }^{13}$ to new data - the grammaticalization process}

\subsubsection{The widening of contexts - metonymic change in early SC}

The first text of a certain length (14,056 words) in SC was written around 1900 (see below). As SC must be considered an offspring of MC (see section 1), it is appropriate to examine early Mauritian texts which have the advantage of going back to the 18th century. As a base of my study, I will work with a corpus of 99,209 words gathered by Philip Baker and Guillaume Fon Sing (Baker \& Fon Sing \& Hookoomsing 2007). The first attestation of the lexeme camarade is found in a case record from $1793 .{ }^{14}$

(13) Early MC

$\begin{array}{lllllll}\text { qu' } & \text { il } & \text { ne vouloir } & \text { pas } & \text { avoir } & \text { la guerre } & \text { avec } \\ \text { COMP } & \text { 3SG } & \text { NEG vouloir } & \text { NEG avoir } & \text { la guerre } & \text { avec } \\ \text { COMP } & \text { 3SG } & \text { NEG want } & \text { NEG have } & \text { war } & \text { with } \\ & & & & & & \\ \text { lui }(\ldots) & \text { ah } & \text { mon dieu } & \text { tirez } & \text { cet } & \text { homme } \\ \text { 3SG.OBJ } & \text { ah } & \text { mon dieu } & \text { tirer } & \text { ART } & \text { homme } \\ \text { 3SG.OBJ } & \text { ah } & \text { my God } & \text { take.away } & \text { ART } & \text { man }\end{array}$

moi n'a pas vouler la guerre camarade

13 For MC, the early data we consider are the data from the period 1721-1929 gathered by Baker \& Fon Sing (eds.) 2007. For SC the first available text is from around 1900 (referred to as early SC), and we do not have any other data before the 1970s. Data starting from 1970 are considered to be modern data for SC and MC.

$14 \quad$ This court case is difficult to classify linguistically because we do not know if we are dealing with a learner's variety of Regional French or if we are justified to speak of Creole. 


\begin{tabular}{|c|c|}
\hline $\begin{array}{l}\text { 1SG NEG } \\
1 \mathrm{SG} N F G\end{array}$ & vouloir \\
\hline
\end{tabular}

'...that he does not want to fight with him. Oh my God, take this man away, I do not want to fight with a companion/other people'. (Fon Sing, corpus de textes anciens en créole mauricien)

The speaker obviously does not want to fight with the previously mentioned referent cet homme, 'this man'. It is highly improbable that he refers to this man - whom he does not seem to know - as being a companion. ${ }^{15}$ Rather, a translation by 'he does not want to fight with others/other people' seems to be more appropriate. Consequently, I researched additional examples because camarade may not only have referred to companions stricto sensu. Here is an example drawn from a catechism of the year 1828. We are dealing with a translation of the 10 Commandments in which the term 'neighbour', or better the French term prochain, is translated by camarade.

(14) Early MC

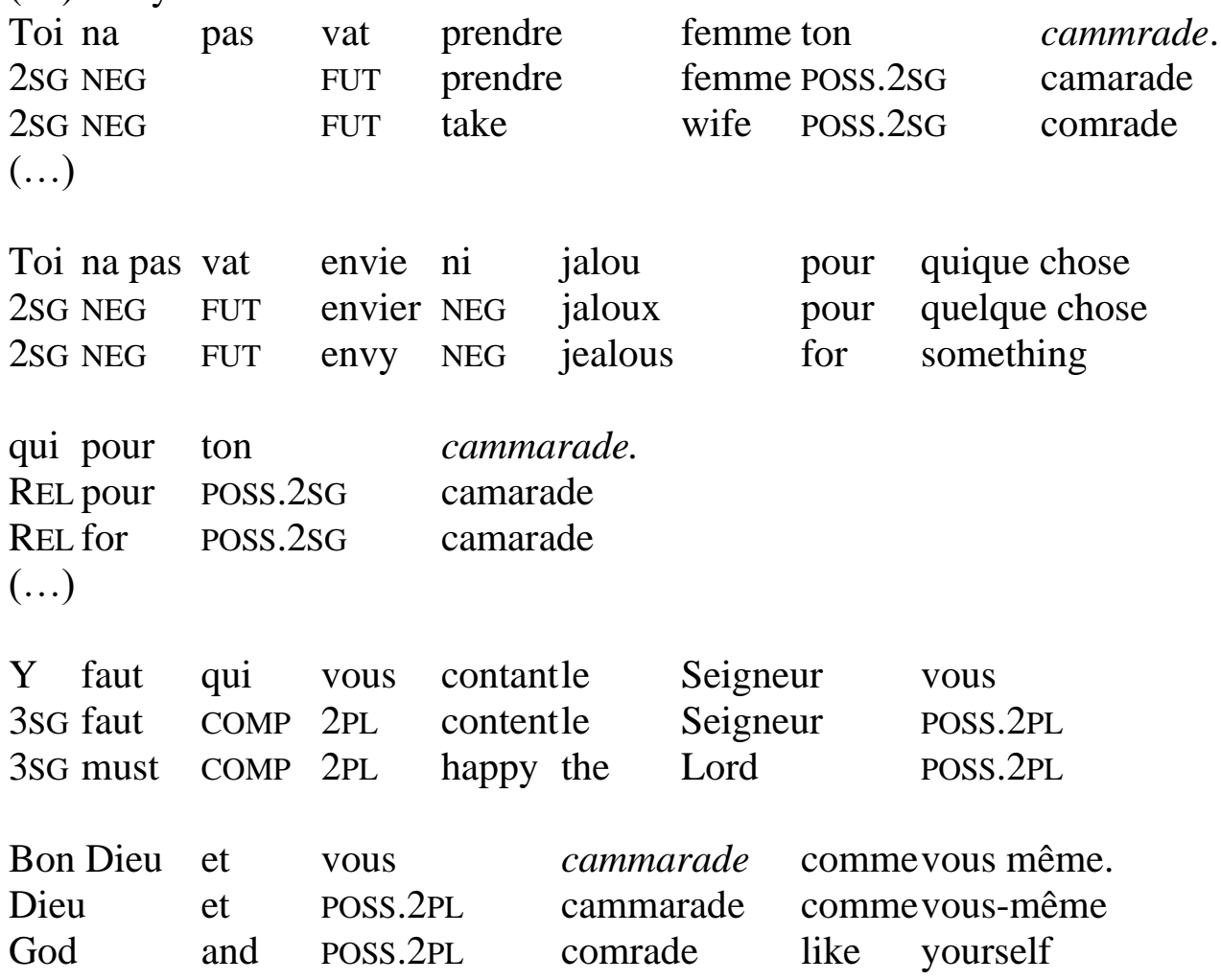

'D: Don't take your neighbour's wife. (...) Don't be envious of goods that belong to your neighbor. (...) You must love your God with your heart and your neighbor as you love yourself.' (Fon Sing, corpus de textes anciens en créole mauricien)

In French, a semantic feature of camarade is clearly 'a familiar person' but its use in the context of the 10 commandments is not attested.

To summarize the use of camarade in early Mauritian texts, we can say that although in most cases it refers, like in French, to a familiar person of the same social condition, we can observe a semantic generalization in some of our examples.

15 Note that this occurrence is one of the very few where camarade is used without any determiner. I do not think that this is sufficient for negating a nominal status as I do for the modern examples. 
Let us now discuss the first occurrences of the word camarade in the only 'early' text in SC, an adaptation of La Fontaine's fables by Rodolphine Young, a Seychellois school teacher (Young 1983). This text was probably written around 1900 but we do not know the exact date (see footnote 13). My first impression was that the token frequency of camarade in Young's text is very high. A comparison with the French original confirms this impression: Out of 14,056 words we find 27 occurrences of camarade in the creole version whereas the corresponding fables of the French version contain 11,475 words with only three occurrences of camarade. Camarade is definitely used much more frequently in the creole adaptation. To examine whether the number of occurrences of the word camarade found in Young's adaptation significantly differs from that found in the corresponding French fables, a $\chi^{2}$ test was performed (see the contingency table in Table 3$)^{16}$.

Table 3. Presence and absence of camarade in La Fontaine's fables and their adaptation into SC by R. Young

\begin{tabular}{|l|l|l|}
\hline & Presence & Absence \\
\hline Young (1983) & 27 & 14,029 \\
\hline French original & 3 & 11,472 \\
\hline
\end{tabular}

The results revealed that the proportion of occurrences of the word camarade is indeed significantly greater in the creole text than in the corresponding French fables $\left(\chi^{2}=13.44 ; p<\right.$ $0.001)$.

(15) Early SC

\begin{tabular}{|c|c|c|c|c|c|c|}
\hline Réna & $\mathrm{y}$ & commence & maziné qui & mangnière & $\mathrm{y}$ & $\mathrm{a}$ \\
\hline Renard & $3 \mathrm{SG}$ & commencer & imaginer & comment & $3 \mathrm{SG}$ & FUT \\
\hline Fox & $3 \mathrm{SG}$ & start & imagine & how & $3 \mathrm{SG}$ & FUT \\
\hline Fai & pou & empèce & son & camarade & riye & li. \\
\hline Faire & pour & empêcher & Poss.3SG & camarade & rire & $3 \mathrm{SG}$ \\
\hline Make & for & prevent & Poss.3sG & comrade & laugh & $3 \mathrm{SG}$ \\
\hline
\end{tabular}

'The fox began to figure out what he would do to prevent the others from laughing at him.' (Young 1983: 27, Le renard ayant la queue coupée)

If we consider the context and the French original of the fable, a translation of son camarade by 'the others' is much more appropriate than a literal translation. In some lines below the author uses les autres, 'the others' in a perfectly similar context.

(16) Early SC

$\begin{array}{llllll}\text { Papa Réna, } & \text { pou } & \text { empèce } & \text { les zot } & \text { ouâ } & \text { son } \\ \text { Papa Renard } & \text { pour } & \text { empêcher } & \text { les autres } & \text { voir } & \text { POSS.3SG } \\ \text { Father Fox } & \text { for } & \text { prevent } & \text { the others } & \text { see } & \text { POSS.3SG }\end{array}$

la qué coupé, y resté assise tout lé temps, lô canapé

queue coupé $3 \mathrm{SG}$ rester assis tout le temps sur canapé

tail cut 3SG stay seated all the time on sofa

'Father Fox, in order to prevent the others from seeing his cut tail, remained sitting on the sofa.' (Young 1983: 27, Le renard ayant la queue coupée) 
A second example from the same text collection given in (17a) is even more convincing because it establishes an opposition between son camarade and son lé kô ('its body'), the other and the self.

(17) Early SC

$\begin{array}{lllll}\text { a. } \begin{array}{l}\text { Çaquine } \\ \text { chacun }\end{array} & \text { y } & \text { ouar, } & \text { défaut son } & \text { camarade. } \\ \text { everybody } & \text { 3SG } & \text { see } & \text { défaut POSS.3SG } & \text { camarade } \\ \text { comrade }\end{array}$

$\begin{array}{llllll}\text { Pas na eine } & \text { qui } & \text { trouve défaut lo } & \text { son } & \text { lé cô. } \\ \text { NEG } & \text { il y a un } & \text { REL } & \text { trouve défaut sur } & \text { POSS.3SG } & \text { corps } \\ \text { NEG } & \text { there is one } & \text { REL } & \text { find fault on } & \text { POSS.3SG } & \text { body }\end{array}$

'Everybody sees other people's faults. Nobody sees his/her own faults.' (Young 1983:

16)

$\begin{array}{lllllll}\text { b. Zot } & \text { tout } & \text { zot } & \text { fine } & \text { ouar } & \text { défaut zott } & \text { camarade. } \\ \text { 3PL } & \text { tous } & \text { 3PL } & \text { PRF } & \text { voir } & \text { défaut POSS.3PL } & \text { camarade. } \\ \text { 3PL } & \text { all } & \text { 3PL } & \text { PRF } & \text { see } & \text { fault POSS.3PL } & \text { comrade. }\end{array}$

'They all have seen the others' faults.' (Young 1983: 16)

We can conclude that in the first text in SC, camarade functions as an independent lexeme, a noun. We are not dealing with grammaticalized uses. No decategorialization in the sense of Bybee (2015: 129-131), Hopper (1991: 30) or Hopper \& Traugott (2003: 106-115) has taken place. Every time Young uses camarade in the meaning 'the others' in her fables, the lexeme appears with the corresponding possessive determiner, in most cases with the $3^{\text {rd }}$ person singular son, but the $3^{\text {rd }}$ person plural $z o t t^{17}$ is also attested (example 17b). Camarade clearly has nominal status.

In the examples discussed above a semantic generalization has occurred, we observe metonymic change. 'Comrades' are part of the whole constituted by 'the others'. Even if the grammaticalization process has not started yet, the conditions for its triggering are fulfilled.

Following Haspelmath (1999), I consider semantic generalization or bleaching to be a prerequisite for the increase in the frequency of a word: "Semantic generalization or bleaching usually is a prerequisite for use in a basic discourse function, that is for the increase in frequency that triggers the other changes". Bybee (2007: 354) also insists on the fact that repetition or increase in frequency is essential to grammaticalization: "Repetition is universal to the grammaticalization process. Repetition and its consequences for cognitive representation are major factors in the creation of grammar". Hopper \& Traugott (2003: 127) state that "the repetition of forms may lead to their 'liberation' or 'emancipation' (Haiman 1994), from their earlier discourse functions and to increased freedom to associate with a wider variety of forms".

In the light of these observations, I argue that the semantic generalization we observe in our examples leads to an increase in frequency (see the high token frequency in Young's fables). This increase by repetition is the prerequisite to the start of grammaticalization proper.

The fact that we do not find grammaticalized uses of camarade in Young's text raises the question of how reciprocity is expressed in the fables: While searching for reciprocal

17 I adopt the original writing. Young alternates between the writing zott and zot but this alternation does not seem to be linked to the desire to distinguish morphosyntactic functions. 
contexts in the fables I found the following examples morphosyntacticly marked by ensembe (Fr. ensemble 'together'), an adverb used to express comitative and related semantic relations.

(18)

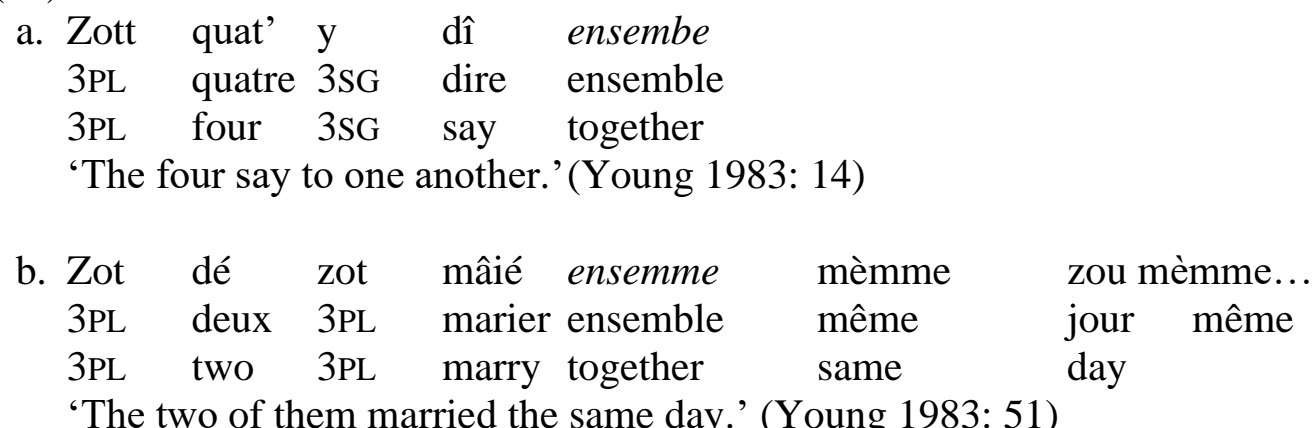

'The two of them married the same day.' (Young 1983: 51)

\subsubsection{ONE single example of grammaticalized use in early MC?}

The only example from the earlier texts, which would allow for an interpretation in terms of grammaticalization, dates from 1860. Note that the example is from MC:

\begin{tabular}{|c|c|c|c|c|c|c|c|c|}
\hline Zote & tous & content & & camrades, & & et & zote & \\
\hline 3PL & tous & content & & RECP/cam & es? & et & 3PL & \\
\hline 3PL & all & love & & RECP/com & S ? & and & 3PL & \\
\hline tous & héré & & a cote & zot & Papa & qui & dans & Ciel \\
\hline Tous & heur & & à côté & POSS.3SG & papa & REL & dans & ciel \\
\hline All & happ & & near & POSS.3SG & $\mathrm{dad}$ & REL & in & heave \\
\hline
\end{tabular}

'They all love one another and they are happy beside their Father who is in heaven.' (De Chazal, Catéchisme créole, Fon Sing, corpus de textes anciens en créole mauricien)

This example corresponds to a use still encountered in modern SC: in the examples given by Choppy (2009), and in corpus example (4) the verb kontan is used in the same way. The absence of the possessive determiner points in the direction of a possible decategoralization. Example (19) can possibly be interpreted as the first and only instance of a grammaticalized use. However, there is a gap of more than 100 years before we can find comparable examples from the second half of the 20th century. Moreover, the grammaticalized examples without possessive determiner emerge in SC and not in MC where the use of the possessive determiner is obligatory (see Section 3.3). In an elicitation task, I asked my consultants to translate the English version of (19) into modern MC. They used the possessive determiner.
(19') MC
Zot tou kontan
zot
kamarad.
3PL tous content
POSS.3SG
camarades
3PL all love
POSS.3SG
comrades

'They all love one another.' 
3.2.3. Further grammaticalization in modern SC: semantic generalization or bleaching, decategorialization, and specialization

In most cases the subject is human but there are some exceptions: see example (1) and (3) which refer to plants and example (7) which refers to body parts.

Kanmarad is even employed with inanimate subjects, for instance in the elicited example (20) in which I asked my consultants to translate an English example:

(20) SC

The mountains almost touch each other.

Consultant 1:

Sa bann montanny i pres pou tous kanmarad.

ARTPL montagne 3SG presque FUT toucherRECP

ARTPL mountain 3SG almost FUT touch RECP

Consultant 2:

$\begin{array}{lllll}\text { Montanny } & \text { i } & \text { preski } & \text { tous } & \text { kanmarad } \\ \text { Montagne } & \text { 3SG } & \text { presque } & \text { toucher } & \text { RECP } \\ \text { Mountain } & \text { 3SG } & \text { almost } & \text { touch } & \text { RECP }\end{array}$

Another example from the translation of the gospel of Mark 13:2 is cited by Bollée (1977: 51):

(21) SC

$\mathrm{Pa} \quad \mathrm{pu}$ reste $\tilde{\mathrm{e}}$ sel $\operatorname{ros}$ lo kamarad.

NEG FUT rester INDF seul roche sur RECP

NEG FUT stay INDF only rock on RECP

'Il ne restera pas pierre sur pierre.' (Bollée 1977: 51)

'Not one stone here will be left on another' (my translation)

- decategorialization (Hopper 1991, Hopper \& Traugott 2003: 106-111; Bybee 2015: 129)

In the corpus examples (1) and (3)-(8), kanmarad is used without determiners. Kanmarad has lost its nominal status and has become a pronoun.

The unidirectional shift from the category noun to the category pronoun is labelled as being an instance of decategorialization. (see Hopper \& Traugott $(2003: 107)^{18}$.

My Seychellois consultants refused to accept the following examples in which a possessive determiner has been introduced:

(22) (1) SC

$\begin{array}{llllllll}\text { *Sa bann } & \text { plant } & \mathrm{i} & \text { pous } & \text { an } & \text { fanmir: } & \text { zot } & \text { pa } \\ \text { ARTPL } & \text { plante } & \text { 3SG } & \text { pousser } & \text { en } & \text { famille } & \text { 3PL } & \text { NEG } \\ \text { ARTPL } & \text { plant } & \text { 3SG } & \text { grow } & \text { in } & \text { family } & \text { 3PL } & \text { NEG }\end{array}$

$\begin{array}{lll}\text { detas } & \text { zot } & \text { kanmarad } \\ \text { détacher } & \text { POSS.3PL } & \text { RECP } \\ \text { pull.away } & \text { POSS.3PL } & \text { RECP }\end{array}$

18 "When a form undergoes grammaticalization from a lexical to a grammatical form, however, it tends to lose the morphological and syntactic properties that would identify it as a full member of a major grammatical category such as noun or verb (Hopper \& Traugott 2003: 107).” 
(23) (3) SC

*Plant ek

Plante avec

plante aussi 3SG

with plant also 3SG

ed son

aider POSS.3SG

kanmarad.

help POSS.3SG

RECP

RECP

(24) (6) SC

*...son de lanmenkrwaze

POSS.3SG deux main croisé

POSS.3SG two hand crossed

son

dans POSS.3SG

kanmarad.

in POSS.3SG RECP

(25) (20) SC

*Sa bann montanny i preski

ARTPL montagne 3SG presque

tous zot

kanmarad.

ARTPL mountain 3SG almost
RECP

touch POSS.3PL RECP

The rejection by my consultants clearly shows that kanmarad has changed its categorial status as a noun and has lost the property of being the head for determiners. In these cases, kanmarad surely must be considered as a pronoun.

- specialization or loss of paradigmatic contrast (Hopper 1991; Hopper \& Traugott 2003: 116-118; Bybee 2015: 125; Lehmann 1995 speaks of paradigmatic variability)

While different items can occur in the position of kanmarad in its not-grammaticalized uses (see the discussion of (12) in section 3.1), this is impossible with its grammaticalized uses, the only alternative often being enn a lot in some contexts (see section 2.1). This fact can be interpreted as a specialization defined as "the process of reducing the variety of formal choices available as the meanings assume greater grammatical generality" (Hopper \& Traugott 2003: 116). My Seychellois consultants did not accept the following examples in which kanmarad has been substituted by zanmi (Fr. ami 'friend').

(26) (1) SC

$\begin{array}{lllll}* \ldots . & \text { Zot } & \text { pa } & \text { detas } & \text { zanmi } \\ \ldots & \text { 3PL } & \text { NEG } & \text { détacher } & \text { ami } \\ \ldots & \text { 3PL } & \text { NEG } & \text { pull.away } & \text { friend }\end{array}$

(27) (3) SC

*Plant ek plant osi i ed zanmi

Plante avec plante aussi 3SG aider ami

Plante with plant also 3SG help friend

(28) (6) SC

*... son de lanmen krwaze dan zanmi

... POSS deux main croisé dans ami

... POSS two hand crossed in friend

(29) (20) SC

*Sa bann montanny i preski tous zanmi

ARTPL montagne 3SG presque toucher ami

ARTPL montagne 3SG presque toucher friend 
After having studied three classical grammaticalization mechanisms at work, I conclude now that kanmarad has become a fully-fledged, unambiguous reciprocal marker in present-day data from SC.

\subsection{Brief comparison with present-day data from $M C$}

After having presented early data from MC and SC and having stated that both languages are still closely related in their modern forms, a study of present-day data from Mauritius now seems to be important. In the absence of corpus examples, I asked my Mauritian consultants ${ }^{19}$ to translate examples from SC.

(30) (4) MC

Mauritian consultant 1 :

$\begin{array}{llllll}\text { Kan } & \text { nou } & \text { ti } & \text { kontan } & \text { nou } & \text { camarade } \\ \text { Quand } & \text { 1PL } & \text { PST } & \text { content } & \text { POSS.1PL } & \text { camarade } \\ \text { When } & \text { 1PL } & \text { PST } & \text { love } & \text { POSS.1PL } & \text { comrade }\end{array}$

$\begin{array}{llllll}\text { moi mo } & \text { ti } & \text { ena } & \text { diset, } & \text { li } & \text { sez. } \\ \text { 1SG 1SG } & \text { PST } & \text { avoir } & \text { dix-sept } & \text { 3SG } & \text { seize } \\ \text { 1SG 1SG } & \text { PST } & \text { have } & \text { seventeen } & \text { 3SG } & \text { sixteen }\end{array}$

Mauritian consultant 2:

$\begin{array}{lllllllll}\text { Ka } & \text { mo } & \text { ti } & \text { ena } & \text { diset } & \text { an } & \text { ti } & \text { ena } & \text { en } \\ \text { quand } & \text { 1SG } & \text { PST } & \text { avoir } & \text { dix-sept } & \text { an } & \text { PST } & \text { avoir } & \text { ART } \\ \text { when } & \text { 1SG } & \text { PST } & \text { have } & \text { seventeen } & \text { year } & \text { PST } & \text { have } & \text { ART }\end{array}$

$\begin{array}{llllll}\text { tifi } & \text { sez an } & \text { nou } & \text { 'nn } & \text { kontan nou } & \text { kamwad. } \\ \text { Fille } & \text { seize an } & \text { 1PL } & \text { PRF } & \text { contentPOSS.1PL } & \text { camarade } \\ \text { Girl } & \text { sixteen year } & \text { 1PL } & \text { PRF } & \text { love POSS.1PL } & \text { camarade }\end{array}$

Rodriguais consultant:

$\begin{array}{lllllllll}\begin{array}{l}\text { Mo ti } \\ \text { 1SG PST }\end{array} & \begin{array}{l}\text { enan diset } \\ \text { avoir dix-sept }\end{array} & \text { an, } & \text { ti } & \text { enan } & \text { enn } & \text { tifi } & \text { ti } \\ \text { 1SG PST } & \text { have } & \text { seventeen } & \text { year } & \text { PST } & \text { have } & \text { ART } & \text { fille } & \text { PST } \\ & & & & & & & & \\ \text { girl } & \text { PST } \\ \text { enan } & \text { sez-an } & \text { nou } & \text { 'nn } & \text { kontan nou } & & \text { kamarad. } \\ \text { avoir } & \text { seize an } & \text { 1PL } & \text { PRF } & \text { contentPOSS.1PL } & \text { camarade } \\ \text { have } & \text { sixteen year } & \text { 1PL } & \text { PRF } & \text { love } & \text { POSS.1PL } & \text { camarade }\end{array}$

'I was seventeen years old, there was a girl who was sixteen, we were in love with each other.'

As can be seen in example (30), the consultants from Mauritius and Rodrigues use kanmarad with the possessive determiner. We are not dealing with a fully grammaticalized use as a reciprocal marker. These kinds of examples reflect the semantic widening prior to grammaticalization which I already discussed for the examples of early MC and SC in section 3.2.1. But in (30) kanmarad still has the semantic feature [+animate].

\footnotetext{
${ }^{19}$ As suggested by the reviewers, I extended my elicitation and added the answers from a consultant from Rodrigues.
} 
While moving lower in the animacy hierarchy (Silverstein 1976) and giving examples with non-animate referents in subject position, the use of kanmarad as a reciprocal marker becomes more and more problematic for the Mauritian consultants:

(31) (18)

Les chevaux se poussent.

$\begin{array}{llllll}\text { MC } & & & & & \\ \text { ?Bann } & \text { souval -la } & \text { pe } & \text { pous } & \text { zot } & \text { kamwad. } \\ \text { PL } & \text { cheval ART } & \text { PROG } & \text { pousser } & \text { POSS.3PL } & \text { camarade } \\ \text { PL } & \text { horse ART } & \text { PROG } & \text { push } & \text { POSS.3PL } & \text { comrade }\end{array}$

$\mathrm{SC}$

Ban seval i pe pous kamarad.

PL cheval 3SG PROG pousser RECP

PL horse 3SG PROG push RECP

'The horses push one another.'

While some Mauritian consultants accepted the use of kanmarad in this example, they insisted on the obligatory use of the possessive determiner, in this case zot (POSS.3PL). Others rejected the example even with the possessive determiner. On the contrary, the Seychellois consultants did not have the slightest hesitation to use kanmarad in this example, without a possessive determiner.

For my Mauritian consultants, the Seychellois example (3) with plants in subject position was inacceptable. They translated it by

\begin{tabular}{|c|c|c|c|c|}
\hline Bann & plant osi & soutenir & zot & ant \\
\hline PL & plante aussi & soutenir & 3PL & entre \\
\hline PI & plant also & support & 3PL & between \\
\hline
\end{tabular}

'Amongst themselves, plants also help one another.'

With one exception, the constructed example with an inanimate referent in (20) was never used with kanmarad by my Mauritian consultants, not even with the possessive determiner.

I conclude that we should speak of incipient grammaticalization in MC. The prerequisites are present: semantic generalization or bleaching is already seen in the early examples and is still present in modern MC. But the use of kanmarad in reciprocal contexts is in general limited to animate referents and must be interpreted as a sign of generalization or bleaching that has not been entirely accomplished. The obligatory use of the possessive determiner shows that decategorialization has not taken place.

\section{Possible motivations for the grammaticalization of kanmarad}

In the last section of this article, I would like to discuss whether the observed grammaticalization process can be explained by any external factors. As I have shown in section 2.3, the use of kanmarad as a reciprocal marker cannot be explained by substrate influence: I did not find any models in the substrate languages of SC. But other external factors could be at the origin of the grammaticalization process I examined in section 3 . So before concluding, I want to discuss two hypotheses: Michaelis \& Haspelmath's (2020) 
Extra-Transparency Hypothesis linked to second language acquisition and my own sociolinguistic hypothesis which I call the Distinction during Codification Hypothesis.

\subsection{The Extra-Transparency Hypothesis (Michaelis \& Haspelmath 2020)}

In recent creole studies, debates have largely centered on "creole exceptionalism", the question whether creoles are special languages. According to some linguists, creoles show great transparency and simplicity (e. g. McWhorter 2001; Parkvall 2008; Bakker \& al. 2011; Leufkens 2013) whereas others insist on the fact that they evolve like any other natural language (e. g. Aboh \& DeGraff 2015; Mufwene 2015) ${ }^{20}$. A slightly different perspective is taken by those who ask themselves if there may have been accelerated change processes in creolization (Bruyn 1996, 2009; Véronique 1999; Kriegel \& Neumann-Holzschuh 2000; Detges 2001; Neumann-Holzschuh \& Schneider 2001; Plag 2002; Bakker 2008). These change processes have been discussed with different terminological proposals whose discussion would be beyond the scope of this paper: reanalysis, acquisitional grammaticalization, instantaneous grammaticalization. Michaelis \& Haspelmath (2020) speak of accelerated grammaticalization: "(...) It appears that grammaticalization is accelerated in creolization." (Michaelis \& Haspelmath 2020) According to them grammaticalization involves three main processes

(i) SEMANTIC CHANGE, which often results in (ii) FUNCTIONALIZATION (content items become function items), and is then followed by (iii) COALESCENCE (cliticization, agglutination, fusion of function item). One central observation of this paper is that English-based, French-based and Ibero-Romance-based creoles show a great deal of functionalization, but little coalescence (though the former content items are often reduced). (Michaelis \& Haspelmath 2020)

Whereas creoles do not show a lot of coalescence, they exhibit a lot of accelerated functionalization. The new function morphemes, so to speak freshly grammaticalized materials, are typical of creole languages and did not exist in grammaticalized uses in the lexifier languages (Michaelis \& Haspelmath 2020; for the example of modals see Kriegel \& Michaelis \& Pfänder 2003). To explain these functionalizations, Michaelis \& Haspelmath (2020) discuss two hypotheses: the Loss-and-Replacement Hypothesis ${ }^{21}$, which they reject because "we favour a hypothesis that is compatible with the view that creoles do not (necessarily) arise from pidgins" and the Extra-Transparency Hypothesis, which they adopt.

\section{Extra-Transparency Hypothesis}

In social situations with many (or even mostly) adult second-language speakers, people need to make an extra effort to make themselves understood. This naturally leads to the overuse of content items for grammatical meanings, which may become fixed when more and more speakers adopt the innovative uses. (Michaelis \& Haspelmath 2020; see also Haspelmath \& Michaelis 2017: 16)

20 McWhorter (2018) insists on the fact "that in creoles, at least early in their life spans, there is indeed more grammaticalization than under ordinary processes of grammar-internal change". Nevertheless, he stresses that grammaticalization in creoles is not of a different nature than grammaticalization in other languages.

$21 \quad$ Loss-and-Replacement Hypothesis

"In the transmission bottleneck of pidginization, inflectional and other non-salient grammatical markers are lost, because they cannot be acquired (e. g. Good 2012). This leaves a void, and when pidgins turn into full-fledged languages again, they need to fill the gaps by new material deriving from content words." (Michaelis \& Haspelmath 2020) 
The authors suggest a list of new grammaticalized materials from several creole languages, materials which, according to them, have developed because of the need for extratransparency in societies with many or mostly second language speakers. Among the new function morphemes, they mention the 'companion'-based reciprocal markers discussed in APiCS and illustrate them with examples from Guianese French Creole, SC, and Creolese.

I find the Extra-Transparency Hypothesis plausible and I am convinced that it can be verified by careful diachronic case studies concerning e. g. TMA markers or other frequently used markers. However, with respect to reciprocity, two problems arise: the rarity of its expression, and, consequently, the paucity of data in MC of SC during the relevant time slot: we have to consider data from the second half of the $19^{\text {th }}$ century when there were a lot of second language speakers after the abolition of slavery in 1835 . Unfortunately, the paucity of examples does not allow making any decisive claims regarding a grammaticalization of kanmarad in this period: As to MC, it is impossible to draw general conclusions based on one isolated example used without a possessive determiner (see example (19)) from the $19^{\text {th }}$ century without confirmation by more recent examples from MC. As to SC, I stated (section 3.2.1) that Young's fables from around 1900, the only available text from Seychelles creole diachrony, do not contain examples that allow for a grammaticalized interpretation. However, this observation is not sufficient to make a safe claim that the construction was grammaticalized only during the $20^{\text {th }}$ century. Consequently, the validity of the ExtraTransparency Hypothesis cannot be verified as far as the grammaticalization of kanmarad in $\mathrm{SC}$ is concerned. However, I would like to retain it as a possible factor that could have contributed to trigger the grammaticalization of kanmarad. As our data base is much more solid for data starting from the 1970s, I would like to discuss another hypothesis which I call the Distinction during Codification Hypothesis.

\subsection{The Distinction during Codification Hypothesis}

SC has been promoted to the status of first national language in 1981, followed by English and French, heritage of the country's colonial past. Seselwa has coexisted with English, rather than French, since 1810 and the role of French today is marginal. The officialization of Creole, which had been an almost exclusively spoken language before, led to an acceleration of its codification (e. g. Bollée \& Kriegel 2016). Today, Creole is the first language of alphabetization, the language of parliament and the main language in oral media. In this context, several morphosyntactic changes have been observed where speakers (and language planners) consciously or unconsciously choose the „déviance maximale“, the maximal distinction from French, the lexifier language when they are confronted with variation. Journalists, writers, and academics dealing with literacy and codification seem to systematically opt for variants which are considered to be the most authentic, the most basilectal, the most creole. This has been shown for the complementizer pourdir (Kriegel 2004) and for the reflexive marker son lekor (Kriegel 1996). ${ }^{22}$ This state of affairs can be formulated in what I call the Distinction during Codification Hypothesis:

\section{The Distinction during Codification Hypothesis}

If a language has to satisfy all communicative needs in all language registers (which is the case for a first national language), we can observe accelerated functionalizations and the stabilization of constructions formerly subject to great variation. In special sociolinguistic

22 The development of a frequently used passive form without restrictions on the verb semantics using ganny (< Fr. gagner - 'to get, to win') as an auxiliary is essentially due to the need for more marked forms in literacy. Additionally, it can be interpreted as the choice of a form that is perceived as being maximally distinct from French. (Kriegel 1996) 
contexts, constructions not found in the lexifier have more chances to become stabilized than those that continue patterns of the lexifier.

The examples (6)-(8), drawn from two recent novels and from the newspaper Seychelles' Nation (2016), can be interpreted as illustrations of this hypothesis. Writers and journalists aware of the autonomy of Creole with respect to the French lexifier and wishing to stress this fact, use techniques associated with Creoleness and veer away from the French model. ${ }^{23}$ This is certainly not the case for the examples (1), (3)-(5) from the oral spontaneous speech of elderly people. However, the fact that the kanmarad-technique is preferred to the "more French" (l)enn a lot-technique in the media and in recent literature is an argument in favor of the validity of the Distinction during Codification Hypothesis. This desire to mark a distinction may contribute to the further expansion and grammaticalization of the kanmaradtechnique.

\section{Conclusion}

I hope I have shown how the grammaticalization of a 'companion'-based reciprocal marker took place in modern SC by discussing several grammaticalization mechanisms and by comparing my data with data from earlier SC texts and from MC. While searching for an external explanation for the studied grammaticalization or, in Michaelis \& Haspelmath's (2020) term, accelerated functionalization, I discussed the Extra-Transparency Hypothesis and the Distinction during Codification Hypothesis, two not mutually exclusive but complementary hypotheses. The Extra Transparency Hypothesis may have contributed to triggering semantic changes prior to functionalization during the second half of the $19^{\text {th }}$ century, and the Distinction during Codification Hypothesis to the grammaticalization and further expansion of the grammaticalized reciprocity marker kanmarad. However, I want to stress the fact that we are dealing with an ordinary language-internal grammaticalization process. Finally, the case study reported here provides evidence that creole languages, once they have stabilized, behave just like any other language.

\section{Acknowledgments}

Ferdinand Vidot, a well-known Seychellois herbalist, died in October 2018. Marcel Rosalie died in December 2019. Thanks to him Ferdinand Vidot was able to share his immense knowledge with us in several informal interviews in 2017. We will forever miss our collaboration. For the examples drawn from these interviews, I refer to the Vidot-Rosalie corpus. Its transcription and translation were carried out by Marcel Rosalie thanks to the support of the project GD 2 La syntaxe de la phrase complexe dans les langues creoles of the Empirical Foundations of Linguistics-Labex and thanks to the support of the Laboratoire Parole et Langage, UMR 7309, CNRS. I would like to thank F. Vidot and M. Rosalie for the time and energy they spent. I am also grateful to Penda Choppy and her team as well as to my Mauritian students and colleagues (above all Rubiena Appa, Shimeen-Khan Chady, Débora

23 Myriam Meyerhoff relates a comparable experience from the codification of Nkep, a very small, indigenous language in Vanuatu. She observes the Nkep dictionary team's "insistence of creating or documenting indigenous forms of words where the common practice is to borrow from Bislama." (Miriam Meyerhoff, p.c.) For Bislama as the national language of Vanuatu, see e.g. Meyerhoff \& Aru (in press). 
Yani Shamir Maury, and Georges Daniel Véronique) who helped me with data elicitation and interpretation. Thanks to Annegret Bollée and to Susanne Michaelis for commenting on a first version of this text and to Michael Pretina and Pauline Welby for reading the text carefully. Last but not least I am grateful to Martin Haspelmath who awarded me a fellowship from the ERC grant "Grammatical universals" in Leipzig during which my interest in dealing with creole reciprocals emerged.

\section{References}

Aboh, Enoch \& Michel DeGraff. 2017. "A null theory of creole formation based on universal grammar". In Ian Roberts (ed.), The Oxford handbook of universal grammar, 401-458, Oxford: Oxford University Press, https://doi.org/10.1093/oxfordhb/9780199573776.013.18

Annamalai, E. 2000. "Lexical anaphors and pronouns in Tamil". B.C. Lust \& al. (eds.), Lexical Anaphors and Pronouns in Selected South Asian Languages, Berlin, New York: Mouton de Gruyter, https://doi.org/10.1515/9783110818888.169

Baker, Philip \& Guillaume Fon Sing. 2007. The making of Mauritian Creole. London: Battlebridge Publications, Westminster Creolistics series, vol. 9.

Baker, Philip \& Guillaume Fon Sing \& Vinesh Y. Hookoomsing. 2007. "The making of Mauritian Creole. Analyses diachroniques à partir des textes anciens". In Philip Baker \& Guillaume Fon Sing (eds.), The making of Mauritian Creole, 1-61, London: Battlebridge Publications, Westminster Creolistics series, vol. 9.

Bakker, Peter. 2008. "The development of tense, mood and aspect in creole languages and the typology of affix order". In Folke Josephson \& Ingmar Söhrman (eds.), Interdependence of diachronic and synchronic analyses (Studies in Language Companion Series, 103), 43-59, Amsterdam: Benjamins, https://doi.org/10.1075/slcs.103.04bak

Bakker, Peter, Aymeric Daval-Markussen, Mikael Parkvall \& Ingo Plag. 2011. "Creoles are typologically distinct from non-creoles". Journal of Pidgin and Creole Languages 26(1). 5-42, https://doi.org/10.1075/jpcl.26.1.02bak

Baissac, Charles. 1880. Etude sur le patois créole mauricien. Nancy: Imprimerie Berger Levrault.

Bollée, Annegret. 1977. Le créole français des Seychelles. Esquisse d'une grammaire - textes - vocabulaire (Zeitschrift für romanische Philologie: Beih.; Bd. 159). Tübingen: Niemeyer, https://doi.org/10.1515/9783111328874

Bollée, Annegret \& Sibylle Kriegel. 2016. „Kodifizierung und Ausbau des Kreolischen der Seychellen“. In Wolfgang Dahmen \& Günter Holtus \& Michael Metzeltin \& Wolfgang Schweickard \& Otto Winkelmann (eds.), Romanische Kleinsprachen heute, 311-324, Tübingen: Narr/Francke/Attempto.

Bruyn, Adrienne. 1996. "On identifying instances of grammaticalization in Creole languages". In Philip Baker \& Anand Syea (eds.), Changing meanings, changing functions. Papers relating to grammaticalization in contact languages (Westminster Creolistics Series 2). 29-46. London: University of Westminster Press.

Bruyn, Adrienne. 2009. "Grammaticalization in creoles: Ordinary and not-so-ordinary cases". Studies in Language 33(2). 312-337, https://doi.org/10.1075/sl.33.2.04bru

Bybee, Joan. 2007. Frequency of use and the organization of language. Oxford: Oxford University Press, https://doi.org/10.1093/acprof:oso/9780195301571.001.0001

Bybee, Joan. 2015. Language Change (Cambridge Textbooks in Linguistics). Cambridge: Cambridge University Press, https://doi.org/10.1017/cbo9781139096768

Choppy, Marie-Thérèse. 2009. Gramer Kreol Seselwa, Mahé: Lenstiti Kreol.

Chaudenson, Robert. 2013. « Approche (historico-) linguistique des créoles des Mascareignes et des Seychelles ». Etudes Océan Indien 49-50: 55-88. 
Corne, Chris. 1977. Seychelles Creole Grammar, Tübingen: Narr.

DECOI 2000 = Bollée, Annegret. 2000. Dictionnaire étymologique des créoles français de l'Océan Indien. Première partie. Mots d'origine française A-D (Kreolische Bibliothek 12/I). Hamburg: Buske.

Detges, Ulrich. 2001. "Two types of restructuring in French creoles: A cognitive approach to the genesis of tense markers". In Ingrid Neumann-Holzschuh \& Edgar Schneider (eds.), Degrees of Restructuring in Creole Languages (Creole Language Library, volume 22), 135-162. Amsterdam: John Benjamins, https://doi.org/10.1075/cll.22.09det

Dryer, Matthew S. \& Haspelmath, Martin (eds.). 2013. The World Atlas of Language Structures Online. Leipzig: Max Planck Institute for Evolutionary Anthropology. (Available online at http://wals.info, Accessed on 2019-07-19.)

Evans, Nicholas. 2008. "Reciprocal constructions: Towards a structural typology". In Ekkehard König \& Volker Gast (eds.), Reciprocals and Reflexives: Theoretical and Typological Explorations, 33-104, Berlin/New York: Mouton de Gruyter, https://doi.org/10.1515/9783110199147.33

Good, Jeff. 2012. "Typologizing grammatical complexities, or: Why creoles may be paradigmatically simple but syntagmatically average". Journal of Pidgin and Creole Languages 27(1), 1-47, https://doi.org/10.1075/bct.57.03goo

Guentchéva, Zlatka \& Nicole Rivière. 2007. "Reciprocal and reflexive constructions in French". In Vladimir P. Nedjalkov (ed.), Reciprocal constructions (5 volumes), 561-607, Amsterdam: John Benjamins, https://doi.org/10.1075/tsl.71.19gue

Hagège, Claude. 2001. "Les processus de grammaticalization". In Martin Haspelmath \& Ekkehard König \& Wulf Oesterreicher \& Wolfgang Raible (eds.), Language Typology and Language Universals. An International Handbook, 1609-1623, Vol. 1, Berlin/ New York: De Gruyter.

Haiman, John. 1994. "Ritualization and the development of language". In William Pagliuca (ed.), Perspectives on Grammaticalization. Amsterdam: Benjamins, 3-28, https://doi.org/10.1075/cilt.109.07hai

Haspelmath, Martin. 1999. "Why is grammaticalization irreversible?". Linguistics 37 (6), 1043-1068, https://doi.org/10.1515/ling.37.6.1043

Haspelmath, Martin. 2013. Chapter 89: "Reciprocal constructions". In Michaelis, Susanne Maria \& Philippe Maurer \& Martin Haspelmath \& Magnus Huber (eds.), Atlas of Pidgin and Creole Language Structures Online. Leipzig: Max Planck Institute for Evolutionary Anthropology. (on line, https://apics-online.info/parameters/89\#2/10.1/4.9)

Haspelmath, Martin \& Susanne Maria Michaelis. 2017. "Analytic and synthetic. Typological change in varieties of European languages". In Isabelle Buchstaller \& Beat Siebenhaar (eds.), Language Variation - European Perspectives VI. Selected papers from the Eighth International Conference on Language Variation in Europe (ICLaVE 8), Leipzig, May 2015, 3-22. Amsterdam: John Benjamins, https://doi.org/10.1075/silv.19.01has

Heine, Bernd \& Tania Kuteva. 2002. World Lexicon of Grammaticalization, Cambridge: Cambridge University Press.

Heine, Bernd \& Tania Kuteva. 2003. "On contact-induced grammaticalization”. Studies in Language 27(3). 529-572.

Heine, Bernd \& Tania Kuteva. 2005. Language contact and grammatical change. Cambridge: Cambridge University Press.

Heine, Bernd \& Hiroyuki Miyashita. 2008. "The intersection between reflexives and reciprocals". In Ekkehard König \& Volker Gast (eds.), Reciprocals and Reflexives: Theoretical and Typological Explorations, 169-224, Berlin/New York: Mouton de Gruyter, https://doi.org/10.1515/9783110199147.169 
Hopper, Paul. 1991. "On some Principles of Grammaticization”. In Elizabeth C. Traugott \& Bernd Heine (eds.), Approaches to grammaticalization (2 volumes), 17-36. Amsterdam/ Philadelphia: Benjamins, https://doi.org/10.1075/tsl.19.1.04hop

Hopper, Paul \& Closs Traugott, Elizabeth. 2003. Grammaticalization. Cambridge: Cambridge University Press, https://doi.org/10.1017/s0022226700000669

Jaozandry, Marie. 2014. "Les prédicats nominaux du Malgache: étude comparative avec le français". Linguistique. Université Paris-Nord - Paris XIII, 2014. Français. 〈NNT : 2014PA131005〉. 〈tel-01236281〉

Jennings, William \& Stefan Pfänder. 2018. Inheritance and innovation in a colonial language. Towards a Usage-Based Account of French Guianese Creole. London \& New York: Palgrave Macmillan, https://doi.org/10.1558/sols.38328

König, Ekkehard \& Florian Haas. 2007. "Typologie du réciproque et constructions réciproques dans les langues créoles". In Karl Gadelii \& Anne Zribi-Hertz (eds.), Grammaires créoles et grammaire comparative, 133-149, Saint Denis: Presses Universitaires de Vincennes.

Kriegel, Sibylle. 1996. Diathesen im Mauritius- und Seychellenkreol. Tübingen: Gunter Narr, ScriptOralia.

Kriegel, Sibylle (ed.). 2003. Grammaticalisation et réanalyse: Approches de la variation créole et française, Paris: CNRS Editions, collection langage.

Kriegel, Sibylle. 2004. "Juste pour dire que pourdir existe toujours". CREOLICA, jeudi 16 décembre 2004, http://www.creolica.net

Kriegel, Sibylle \& Ingrid Neumann-Holzschuh. 2000. "Présentation: L'évolution grammaticale des créoles. Problèmes et perspectives". Etudes Créoles Vol.XXIII, n²2000, 5-24.

Kriegel, Sibylle \& Susanne Michaelis \& Stefan Pfänder. 2003. "Modalité et grammaticalisation: le cas des créoles français". In Sibylle Kriegel (ed.), Grammaticalisation et réanalyse. Approches de la variation créole et française, 165-192. Paris: CNRS Editions, collection langage.

Kriegel, Sibylle \& Ralph Ludwig \& Stefan Pfänder. 2019. "Dialectes - créolisation convergence. Quelques hypothèses à partir du berrichon et du poitevin-saintongeais". In Andreas Dufter \& Klaus Grübl \& Thomas Scharinger (eds.), Des parlers d'oül à la francophonie: contact, variation et changement linguistique, 299-347. Berlin: De Gruyter, Beihefte zur ZrP, https://doi.org/10.1515/9783110541816-013

Lehmann, Christian. 1995. Thoughts on Grammaticalization. München: Lincom Europa, First publication: 1982, akup 48, University of Cologne, https://doi.org/10.26530/oapen_603353

Leufkens, Sterre. 2013. "The Transparency of Creoles". Journal of Pidgin and Creole Languages 28(2), 323-362, https://doi.org/10.1075/jpcl.28.2.03leu

Maslova, Elena. 2007. "Reciprocal and polyadic (remarkable reciprocals in Bantu)". In Vladimir P. Nedjalkov (ed.), Reciprocal constructions, 335-352, Amsterdam: John Benjamins, https://doi.org/10.1075/tsl.71.11mas

Maslova, Elena \& Vladimir P. Nedjalkov. 2013. "Reciprocal Constructions". In Matthew S. Dryer \& Martin Haspelmath (eds.), The World Atlas of Language Structures Online. Leipzig: Max Planck Institute for Evolutionary Anthropology. (Available online at http://wals.info/chapter/106, Accessed on 2020-05-12.)

McWhorter, John H. 2001. "The world's simplest grammars are creole grammars". Linguistic Typology 5(2-3). 125-166, https://doi.org/10.1515/lity.2001.001

McWhorter, John H. 2018. "Is grammaticalization in creoles different?”. In Heiko Narrog \& Bernd Heine (eds.), Grammaticalization from a Typological Perspective, Oxford: Oxford Scholarship Online, https://doi.org/10.1093/oso/9780198795841.003.0019 
Meyerhoff, Miriam \& Carol C. Aru (in press). "Bislama (Vanuatu)". In Kingsley Bolton (ed.) The Wiley Blackwell Encyclopedia of World Englishes. Oxford: Wiley Blackwell.

Michaelis, Susanne Maria \& Philippe Maurer \& Martin Haspelmath \& Magnus Huber (eds.). 2013. Atlas of Pidgin and Creole Language Structures Online. Leipzig: Max Planck Institute for Evolutionary Anthropology. (Available online at http://apics-online.info, Accessed on 2020-06-04.)

Michaelis, Susanne Maria \& Rosalie, Marcel. 2013. "Seychelles Creole". In Michaelis, Susanne Maria \& Maurer, Philippe \& Haspelmath, Martin \& Huber, Magnus (eds.) The survey of pidgin and creole languages. Volume 2: Portuguese-based, Spanish-based, and French-based Languages. Oxford: Oxford University Press. (Available online at http://apics-online.info, Accessed on 2020-06-04.)

Michaelis, Susanne Maria \& Martin Haspelmath. 2020. "Grammaticalization in creole languages: Accelerated functionalization and semantic imitation". In Andrej Malchukov \& Walter Bisang (eds.), Grammaticalization Scenarios: Cross-linguistic variation and universal tendencies. Berlin: Mouton/DeGruyter, 1109-1128, https://doi.org/10.1515/9783110712735-013

Mufwene, Salikoko. 2015. "L'émergence des parlers créoles et l'évolution des langues romanes: fait, mythes et idéologies". Études créoles, nouvelle série 1 (2015), 11-37. http://www.lpl-aix.fr/productions/edition/revue-etudes-creoles/.

Nedjalkov, Vladimir P. 2007 (ed.). Reciprocal constructions. 5 volumes, Amsterdam: John Benjamins, https://doi.org/10.1075/tsl.71

Neumann-Holzschuh, Ingrid \& Edgar W. Schneider (eds.). 2001. Degrees of Restructuring in Creole Languages, Amsterdam: John Benjamins, https://doi.org/10.1075/cll.22

Neumann-Holzschuh, Ingrid. 2001. 'Restructurations dans un créole 'conservateur'. Le cas du créole louisianais". In Ingrid Neumann-Holzschuh \& Edgar W. Schneider (eds.), Degrees of Restructuring in Creole Languages, 383-407. Amsterdam: John Benjamins, https://doi.org/10.1075/cll.22.20neu

Parkvall, Michael. 2008. The simplicity of creoles in a cross-linguistic perspective. In Matti Miestamo \& Kaius Sinnemäki \& Fred Karlsson (eds.), Language complexity. Typology, contact, change, 265-285. Amsterdam/Philadelphia: Benjamins, https://doi.org/10.1075/slcs.94.17par

Plag, Ingo. 2002. "On the role of grammaticalization in creolization". In Glenn Gilbert (ed.), Pidgin and creole linguistics in the 21st century, 229-246. New York: Peter Lang, https://doi.org/10.1075/tsl.49.08hei

Raible, Wolfgang. 1992. Junktion. Eine Dimension der Sprache und ihre Realisierungsformen zwischen Aggregation und Integration, Heidelberg: Carl Winter, Universitätsverlag, https://doi.org/10.2307/415870

Roberts, I. \& A. Roussou 2003. Syntactic Change. A Minimalist Approach to Grammaticalization. Cambridge: CUP, https://doi.org/10.1017/cbo9780511486326

Schladt, Mathias. 1996. Reciprocals in Bantu. Ms. University of Cologne.

Silverstein, Michael. 1976. "Hierarchy of features and ergativity". In R.M.W. Dixon (ed.), Grammatical categories in Australian languages, 112-171, Canberra: Australian Institute of Aboriginal Studies, https://doi.org/10.1515/9783110871661-008

Syea, Anand. 2013. The Syntax of Mauritian Creole, London etc.: Bloomsbury, https://doi.org/10.5040/9781472542168

Véronique, Daniel. 1999. "L'émergence de catégories grammaticales dans les langues créoles: grammaticalisation et réanalyse ». In Jürgen Lang \& Ingrid Neumann-Holzschuh (eds.), Reanalyse und Grammatikalisierung in den romanischen Sprachen, 187-209. Tübingen: Niemeyer, https://doi.org/10.1515/9783110924824-012 
$F E W=$ Wartburg, Walther von (1922-2002), Französisches etymologisches Wörterbuch. Eine Darstellung des galloromanischen Sprachschatzes, Bd. 1 - 25, Berlin, Leipzig, Bonn, Tübingen, Basel, https://apps.atilf.fr/lecteurFEW/index.php/

Wiesinger, Evelyn. 2017. Le syntagme nominal en créole guyanais. Une étude synchronique et diachronique du marqueur LA, Hamburg: Buske, Kreolische Bibliothek.

Woodward, Herbert W. 1926. An outline of Makua grammar. Bantu Studies 2: 269-325, https://doi.org/10.1080/02561751.1923.9676189

\section{Corpora:}

Bollée, Annegret \& Marcel Rosalie. 1994. Parol ek memwar. Récits de vie des Seychelles, Hamburg: Buske, Kreolische Bibliothek.

Dick, Thérésia. 2016. Pti Piman For, Seychelles.

Fon Sing, Guillaume. Corpus de textes anciens en créole mauricien. http://concordancemmc.free.fr/

Seychelles Nation, http://www.nation.sc/

Interviews of National Heritage, recorded in 1983, speaker: Jolicoeur, ms.

Parépou, Alfred. 1987 [1885]. Atipa (roman guyanais). Traduit et annoté par Marguerite Fauquenoy (GEREC Textes, Etudes et Documents 1987, n 4-5)). Paris: L'Harmattan.

Vel, Aneesa. Forthcoming. Latet par lao delo. Lakaz Sen Zosef, Au Cap: Lenstiti Kreol.

Vidot-Rosalie corpus. Oral corpus in collaboration with Marcel Rosalie, Seychelles 2017, ms.

Young, Rodolphine. 1983. Fables de La Fontaine traduites en créole seychellois. Hamburg: Buske, Kreolische Bibliothek. 